\title{
PENERAPAN KEWIRAUSAHAAN PADA PENGUSAHA KECIL
}

\author{
${ }^{1}$ Rosmiati, ${ }^{2}$ Irwan, ${ }^{3}$ Syahrul Bahari \\ ${ }^{1,2,3}$ Politeknik Negeri Kupang \\ *E-mail: rosmiati99@gmail.com
}

\begin{abstract}
Abstrak
Tujuan penelitian ini mendapatkan gambaran usaha kecil dalam menjalankan kewirausahaan. Permasalahnya masih ada masyarakat yang kurang berminat pelaksanaan usaha. Pengumpulan data dilakukan dengan melakukan survei lapangan menggunakan kuesioner, data dikumpulkan melalui kuesioner. Hasil penelitian menunjukkan nilai $R$-square $(0,188)$ yang termasuk katagori rendah atau lemah. Demikian pula dengan hasil pengujian hipotesis dengan uji $F$ yang menunjukkan bahwa F-hitung $\leq$ F-tabel $(0,313 \leq 3,683)$ yang artinya variabel sikap, motivasi dan minat tidak berpengaruh signifikan terhadap peluang usaha. Hal itu disebabkan karena sebagian besar responden sampel belum memahami tentang kewirausahaan serta sebagian besar masyarakat belum mempunyai minat berwirausaha. Untuk itu penelitian ini akan terus dikembangkan sampai ada sikap, motivasi dan minat berwirausaha. Memberikan wawasan berwirausaha merupakan suatu pilihan masa depan yang lebih baik dengan memberikan bimbingan wirausaha, memupuk jiwa kewirausahaan melalui pelatihan kewirausahaan dan melatih kepercayaan diri, diharapkan akan mengubah pendapat bahwa wirausaha dapat menjanjikan kehidupan yang lebih baik.
\end{abstract}

Kata Kunci: Kewirausahaan, sikap, motivasi, minat, peluang usaha, pilihan masa depan

\section{PENDAHULUAN}

Dasar membangkitkan semangat kewirausahaan di Indonesia ditetapkan oleh pemerintah telah mengeluarkan Instruksi Presiden nomor 4 tahun 1995 dengan tujuan semangat kepelaporan di kalangan generasi muda agar mampu menjadi wirausaha. Kewirausahaan dapat dikatakan sebagai kemampuan untuk melakukan usaha mandiri, artinya seseorang dapat melakukan usaha tanpa terikat atau kertergantungan pada orang lain dan memiliki kemampuan untuk hidup mandiri dalam menjalankan kegiatan usahanya dia bebas merancang, mengelola, menentukan, mengendalikan usahanya.

Zimmerer dalam Sukardi (2014) mengatakan bahwa salah satu faktor pendorong pertumbuhan kewirausahaan disuatu negara terletak pada peranan universitas melalui penyelenggaraan pendidikan kewirausahaan. Hasil penelitian Suharti (2011) tentang faktor-faktor yang berpengaruh terhadap minat kewirausahaan menyebutkan bahwa signifikasi dari faktorfaktor sikap, yaitu faktor ekonomi dan otoritas faktor realisasi diri, faktor keyakinan, dan faktor-faktor keamanan dalam mempengaruhi minat kewirausahaan mahasiswa.

Penelitian Mulyatiningsih (2007) tentang Analisis kesenjangan kompetensi kewirausahaan antara industri dan mahasiswa teknik boga menyimpulkan rerata kompetensi kewirausahaan industri selalu lebih tinggi dari rerata kewirausahaan mahasiswa. Kewirausahaan pada hakikatnya adalah sifat, ciri dan watak seseorang yang memiliki kemauan dalam mewujudkan gagasan inovatif ke dalam dunia nyata secara kualitatif.

Penelitian ini menfokuskan pada pengusaha kecil yang ditujukan pada pedagang kecil sebagai penunjang perekonomian keluarganya. Pedagang kecil yang dimaksud adalah pengusaha dadakan artinya mereka menjual sebatas menjual bahan-bahan kebutuhan rumah tangga berupa sayur mayur, dan hasil pertanian lainnya dengan modal tidak melebihi Rp 500.000,-. Pedangan kecil tersebut telah mengangkat ekonomi keluarga dan menghilangkan pengangguran yang menjadi momok yang menakutkan bangsa ini. Penghasilan mereka tidak seberapa namun walau sedikit masih tetap ada. Perjuangan hidup sebagai bekal untuk menapaki kemandirian hidup ini sangat dibutuhkan di lingkungan masyarakat dengan kondisi yang minim lapangan kerja seperti di negara kita saat ini. Hal tersebut diperparah dengan banyaknya calon tenaga kerja yang kurang terampil sehingga semakin mempersempit kesempatan untuk bekerja. Maka dibutuhkan suatu cara untuk menumbuhkan semangat 
kemandirian di lingkungan masyarakat yang masih produktif dengan konsep kewirausahaan. Dengan kewirausahaan diharapkan akan dapat menunjang pemberdayaan masyarakat agar lebih produktif di berbagai bidang. Kewira usahaan sangat dibutuhkan bagi setiap pelaku usaha, tidak terkecuali kelompok pengusaha kecil desa Baumata tersebut, mereka butuh binaan dan perlu dibina terutama bagaimana mereka membeli dan mejualnya kembali.

Peluang usaha terdiri dari dua kata yaitu "peluang" dan "usaha". Peluang yang dalam bahasa Inggris di sebut dengan opportunity memiliki arti sesuai dengan KBBI adalah kesempatan. Secara sederhana peluang di artikan sebagai kesempatan muncul atau terjadi pada satu peristiwa. Sementara itu, usaha memiliki pengertian berbagai daya untuk mendapatkan apa yang di inginkan. Sehingga secara terminologis pengertian peluang usaha adalah kesempatan yang dapat dimanfaatkan seseorang untuk mendapatkan apa yang di inginkannya (keuntungan kekayaan - uang) dengan memanfaatkan berbagai faktor baik faktor eksternal maupun internal.

(Anonim, 2015) dalam menilai sebuah peluang usaha, apakah cocok dengan keadaan kita atau tidak, tentu kita harus memperhatikan berbagai faktor yang saya bagi menjadi dua jenis yaitu :

1) Faktor Internal :

Faktor internal berasal dari diri kita sendiri semisal bakat dan minat. Mungkin bagi orang lain usaha bimbingan belajar komputer menjadi satu peluang bisnis yang sangat prospektif, namun bagi mereka yang bahkan SD tidak lulus sementara umur sudah terlanjur tua. Maka ini akan sangat sulit berkembang. Saya tidak mengatakan bahwa mustahil untuk sukses, namun keberhasilan akan lebih lama bahkan bisa jadi akan menemui kegagalan di tengah jalan. Untuk itulah, ketika kita memilih satu peluang usaha maka terlebih dahulu kita harus melihat faktor internal yang ada dalam diri kita agar apa yang kita inginkan yaitu keuntungan bisnis, dan kekayaan dapat kita raih dengan lebih mudah dan cepat.

2) Faktor Eksternal

Faktor eksternal berarti berbagai hal yang berkaitan di luar diri kita. Warnet adalah salah satu peluang usaha yang dulu pernah booming dan menghasilkan banyak uang untuk pemiliknya. Namun, pada beberapa tahun terakhir, usaha ini mulai surut karena munculnya banyak laptop, gadget serta area internet gratis. Bagi sebagian daerah mungkin masih berpotensi, namun bagi daerah yang kebanyakan warganya telah memiliki laptop dan jaring internet sendiri. Maka peluang usaha warnet akan menjadi ide usaha yang kurang tepat terlebih kini telah banyak muncul desa internet yang mengembangkan desanya dengan memaksimalkan fungsi internet serta memberikan akses internet dengan mudah dari dalam rumahnya. Faktor eksternal ini harus anda kaji dengan baik. Caranya adalah buka mata, buka telinga dan jadilah orang yang bisa tanggap dalam menghadapi berbagai perubahan dunia. Tren selalu berubah, dulu, bunga cinta menjadi sangat fenomenal dengan harga yang selangit, kini bunga tersebut entah kemana rimbanya. Ini adalah contoh perubahan tren yang mempengaruhi dunia bisnis.

Jika anda bisa melihat kedua faktor di atas, maka anda nantinya bisa membaca peluang bisnis dengan baik sehingga anda bisa memanfaatkan kesempatan tersebut untuk mendapatkan banyak uang. Menurut seorang tokoh bisnis dunia, D.J Schwarts, agar peluang usaha bisa kita maksimalkan untuk hasil yang optimal maka kita perlu melakukan beberapa hal di bawah ini di antaranya :

\section{Percaya dan yakin}

Bagi anda yang pernah membaca buku - buku motivasi seperti law of atraction, mungkin anda akan paham betapa dahsyatnya kekuatan keyakinan. Ketika kita yakin, ada tarikan dalam diri kita untuk mendapatkan kekuatan alam sehingga kita terdorong untuk melakukan hal - hal agar sukses. Alam pun kemudian menarik kekuatannya dan menggerakan alam agar apa yang kita yakini benar benar terjadi. Soekarno pernah berkata " Jika kita mempunyai keinginan yang kuat dari dalam hati, maka seluruh alam semesta akan bahu - membahu mewujudkannya"

2. Jangan hadiri lingkungan yang statis yang akan melumpuhkan pikiran wirausahawan.

Maksudnya pilihlah sahabat yang tepat. Jika anda terbiasa bergaul dengan mereka yang memiliki pemikiran sempit maka anda akan menjadi orang yang memiliki pemikiran yang tidak jauh dari mereka. Anda terbiasa dengan mereka 
yang memiliki sikap pesimis, maka anda pun kemungkinan besar akan menjadi seorang yang skeptis terhadap kemampuan anda sendiri. Untuk itu, bergaullah dengan mereka yang telah sukses, kemudian carilah orang orang yang selalu optimis agar ketika anda merasa kecil hati, anda bisa tahu bagaimana mereka bisa membesarkan hati mereka ketika keadaan sedang tidak menentu.

Dua hal diatas adalah beberapa hal yang harus anda lakukan agar anda bisa sukses, masih ada beberapa point penting yang sebenarnya juga harus anda pelajari selengkapnya bisa anda baca di artikel berikut ini, seorang pengusaha merupakan seorang yang menggabungkan sumber daya, tenaga kerja, bahan baku, serta aset lain untuk menghasilkan nilai yang lebih besar dari sebelumnya, juga seorang yang mengenalkan perubahan, inovasi, dan tantangan baru.

Hisrach (2001) mengemukakan bahwa kewirausahaan diartikan sebuah proses dinamis dalam menciptakan tambahan kekayaan, kekayaan oleh individu yang menanggung resiko utama dalam hal modal waktu, dan/atau komitmen karier atau menyediakan nilai bagi beberapa produk atau jasa. Produk atau jasa mungkin dapat terlihat unik ataupun tidak, tetapi dengan berbagi cara nilai akan dihasilkan oleh seseorang pengusaha dengan menerima dan menempatkan ketrampilan dan suber daya yang dibutuhkan. Selanjutnya Hisrich (2001) menjelaskan lagi bahwa kewirausahaan (entrepreneurship) adalah proses penciptaan sesuatu yang baru pada nilai menggunakan waktu dan upaya yang diperlukan, menanggung resiko keuangan, fisik, serta resiko sosial yang mengiringi, menerima moneter yang dihasilkan, serta kepuasan dan kebebasan pribadi.

\footnotetext{
Definisi kewirausahaan menekankan empat aspek dasar menjadi seorang pengusaha: (1). Melibatkan proses penciptaan, menciptakan suatu nilai baru. (2). Menuntut sejumlah waktu dan upaya yang dibutuhkan. (3). Melibatkan seseorang menjadi pengusaha, penghargaan yang paling penting adalah kebebasan, lalu kepuasan pribadi. (4). Pengusaha akan merespon dan menciptakan perubahan melalui tindakan, sedangkan tindakan wirausahaan menyatu pada perilaku sebagai bentuk tanggapan atas keputusan yang didasarkan pada pertimbangan ketidak pastian mengenai peluang yang mungkin untuk mendapatkan keuntungan
}

Proses untuk mengembangkan sebuah usaha baru terjadi pada proses kewirausahaan (entreupreneur process), yang melibatkan lebih dari sekedar penyelesaian masalah dalam suatu posisi manajemen. Seorang pengusaha harus menemukan, mengevaluasi, dan mengembangkankan sebuah peluang dengan mengatasi kekuatan yang menghalangi terciptanya suatu yang baru. Proses ini memilki empat tahap yang berbeda ; (1.). Identifikasi dan evaluasi peluang. (2). Pengembangan rencana bisnis. (3). Penetapan sumber daya yang dibutuhkan. (3). Manajemen perusahaan yang dihasilkan.

Identitas peluang dan evaluasi merupakan tugas yang sangat sulit, sebagian besar peluang bisnis yang baik tidak muncul secara tiba-tiba melainkan merupakan hasil ketajaman seseorang pengusaha melihat kemungkinan pada beberapa kasus, pembentukan mekanisme yang dapat mengidentifikasi peluang potensial.

Penelitian ini bertujuan untuk mengetahui sikap, minat dan motivasi pegusaha kecil dalam melihat peluang usaha karena pengusaha kecl tersebut diperkirakan belum melihat peluang usaha karena kurang memperhatikan minat dan motivasinya dalam berusaha. Maka peneliti mengadakan penelitian yang bersifat memberi wawasan usaha untuk melihat peluang usaha bagi pengusaha kecil. Hasil penelitian ini juga diharapkan mampu menambah hasil penelitian dalam ilmu ekonomi dalam bidang kewirausahaan, selain itu diharapkan mampu menjadi sumber rujukan bagi para peneliti untuk terus mengkaji dan melakukan penelitian lebih lanjut mengenai hal yang serupa yaitu model kewirausahaan bagi pengusaha sebagai pendukung industri pariwisata.

\section{METODE PENELITIAN}

Penelitian ini dilakukan di Desa Baumata Barat dengan alasan pemilihan lokasi tersebut dikarenakan adanya pengusaha kecil menjajakan dagangannya untuk kebutuhan konsumen. Sasaran penelitian ini antara lain mendapatkan gambaran minat pengusaha kecil menjalankan wirausaha, dengan melihat beberapa variabel antara sikap dan motivasi yang menumbuhkan minat wirausaha dalam melihat peluang usaha.

Metode penelitian ini adalah survei lapangan dengan melakukan penyebaran kuesioner secara langsung ke responden untuk menguji faktor - faktor yang 
mempengaruhi sikap, motivasi dan minat wirausaha mahasiswa. Metode pengumpulan data menggunakan instrumen kuesioner dengan sampel responden sebanyak 20 orang dari populasi secara acak. Teknik sampling adalah simple random sampling (acak) dengan tingkat kesalahan $5 \%$. dari daftar pengambilan sampel yang dianggap representatif menurut (Sugiyono, 2003). Prinsip pemilihan sampel dalam desain ini adalah setiap elemen dalam populasi mempunyai kesempatan yang sama untuk dipilih (Kuncoro, 2003). Metode analisis data dengan pendekatan analisis kuantitatif, data diolah dan dianalisis dengan menggunakan bantuan software SPSS for Windows seri 16.0 .

Variabel penelitian ini terdiri dari variabel peluang usaha sebagai variabel terikat (dependent variable) dan variabel sikap, minat dan motivasi sebagai variabel bebas (independent variabel). Data yang digunakan dalam penelitian ini meliputi data primer dan data sekunder.

a) Data Primer

Data primer merupakan data yang dikumpulkan dan disatukan secara langsung dari obyek yang diteliti untuk kepentingan penelitian. Data primer dari penelitian ini berasal dari responden seperti jawaban atas daftar pertanyaan yang peneliti berikan pada mahasiswa yang jadi sasaran, berupa data yang berkaitan dengan variabe-variabel yang akan diteliti, yaitu tentang pengetahuan wirausaha, skala usaha, pengalaman usaha, jenis usaha, penggunaan informasi akuntansi

\section{b) Data Sekunder}

Data sekunder merupakan data yang dikumpulkan oleh studi-studi sebelumnya atau yang diterbitkan oleh berbagai penelitian yang sudah dipublikasikan atau memanfaatkan data yang sudah ada. Data sekunder yang digunakan dalam penelitian ini diperoleh dari perpustakaan atau jurnaljurnal.

Instrumen dikatakan valid apabila instrument tersebut dapat dengan tepat mengukur apa yang hendak diukur. Dengan kata lain validitas berkaitan dengan dengan ketepatan dengan alat ukur (Widoyoko, 2012). Uji validitas dan reliabilitas dilakukan dengan menggunakan software SPSS for Windows seri 16.0. Suatu kuesioner dikatakan valid apabila pertanyaan atau penyataan pada kuesioner mampu mengungkapkan s esuatu yang akan diukur oleh kuesioner tersebut. Dalam penelitian ini uji validitas dilakukan dengan melihat hasil corrected item-total correlation dengan ketentuan bahwa variabel yang diteliti dinyatakan valid apabila nilai corrected itemtotal correlation adalah lebih besar bila dibandingkan dengan $r_{\text {tabel }}$ (Santoso, 2002).

Uji reliabilitas digunakan untuk mengukur suatu kuesioner yang merupakan indikator dari variabel. Suatu kuesioner dikatakan reliabel apabila jawaban seorang sampel terhadap pernyataan bersifat konsisten dari waktu ke waktu. Pengukuran realibilitas dalam penelitian ini dilakukan dengan uji statistik Cronbach's Alpha dengan ketentuan bahwa variabel yang diteliti dinyatakan reliabel apabila nilai Cronbach's Alpha > 7.00 (Santoso, 2002).

Data yang telah terkumpul kemudian dilakukan pengolahan data dengan menggunakan cara sebagai berikut :

1. Pemeriksaan data (editing), sebelum dilakukan pengolahan data, perlu data tersebut diperiksa lebih dahulu. Jadi dalam penelitian ini disediakan instrument angket yang berisi 20 pertanyaan mengenai pengetahuan wirausaha.

2. Pembuatan kode (coding), melakukan coding terhadap data yang sudah diedit,sebagai usaha untuk menyederhanakan data, yaitu dengan memberi tanda di angka 1-5 pada masingmasing kategori jawaban dari seluruh responden. Adapun nilai sangat setuju diberi kode dengan skor 5, nilai setuju diberi skor 4, nilai kurang setuju diberi skor 3 , nilai tidak setuju diberi skor 2 , dan nilai sangat tidak setuju diberi skor 1 .

Hipotesis yang dibangun dalam penelitian ini adalah sebagai berikut :

- Ho: $\beta 1=\beta 2=0$, Variabel sikap, minat dan motivasi tidak berpengaruh signifikan terhadap peluang usaha

- $\mathrm{Ha}:$ : $\beta 1 \neq \beta \quad 2 \neq 0$, Variabel sikap, minat dan motivasi berpengaruh signifikan terhadap peluang usaha.

Dengan kriteria penilaian sebagai berikut:

- $\mathrm{F}$ hitung $\leq \mathrm{F}$ tabel $=$ Ho diterima

- $F$ hitung $>\mathrm{F}$ tabel $=$ Ho ditolak, Ha diterima.

Data yang terkumpul kemudian diolah dan dianalisis dengan menggunakan bantuan software SPSS for Windows seri 16.0. Analisa data menggunakan analisis regresi linier berganda, yang merupakan salah satu bagian analisis yang amat penting dalam metode ilmiah karena dengan analisa data tersebut 
dapat diberi arti, memiliki makna yang berguna dalam memecahkan masalah.

\section{HASIL DAN PEMBAHASAN}

Penelitian ini dilaksanakan di Desa Baumata Barat Kecamatan Taebenu Kabupaten Kupang Propinsi Nusa Tenggara Timur. Penduduknya berjumlah 2.509 jiwa yang terdiri dari laki-laki 1.231 jiwa dan perempuan berjumlah 1.278 jiwa. Mata pencahariannya bermacam profesi mulai dari pengawai negeri sipil (PNS), karyawan, pengusaha, petani, buruh dan nelayan, dan untuk lebih jelasnya dapat dilihat pada Tabel 1 berikut ini:

Tabel 1. Pekerjaan Masyarkat Desa Baumata Barat

\begin{tabular}{|c|l|r|}
\hline NO & PEKERJAAN & \multicolumn{1}{|c|}{ JUMLAH (JIWA) } \\
\hline 1 & PNS & 254 \\
\hline 2 & Swasta & 313 \\
\hline 3 & Petani & 103 \\
\hline 4 & Usaha Dagang & 18 \\
\hline 5 & Wirausaha & 189 \\
\hline 6 & Belum Bekerja & 1.632 \\
\hline \multicolumn{2}{|c|}{ Total } & 2.509 \\
\hline \multicolumn{2}{|c|}{ Sumber : data primer diolah }
\end{tabular}

Berdasar data tersebut di atas pekerjaan wirausaha masih tergolong sangat rendah yang hanya mencapai $7,2 \%$ sedangkan peluang usaha tersebut sangat terbuka bagi orang orang yang belum bekerja sebesar $65 \%$. Tidak ada kata istilah pengangguran artinya peluang usaha sangat terbuka bagi siapa saja termasuk yang belum bekerja dengan ketentuan ada pembinaan kewirausahaan dari pemerintah setempat. Agama yang dianut masyarakat Desa Baumata Barat yaitu ada lima agama terdiri dari Protestan sebanyak 1.470 jiwa atau $58,6 \%$, Katholik 717 jiwa $(28,6 \%)$, Islam 280 jiwa $(11,2 \%)$ dan Hindu 42 jiwa $(1,6 \%)$. Tabel pendidikan masyarakat Desa Baumata Barat di sajikan pada Tabel 2 berikut ini:

Tabel 2. Tingkat Pendidikan

\begin{tabular}{|c|l|r|}
\hline NO & \multicolumn{1}{|c|}{ PEKERJAAN } & JUMLAH(ORANG) \\
\hline 1 & Sekolah Dasar & 530 \\
\hline 2 & $\begin{array}{l}\text { Sekolah Menengah } \\
\text { Pertama }\end{array}$ & 355 \\
\hline 3 & Sekolah Menengah Atas & 723 \\
\hline 4 & Diploma & 51 \\
\hline 5 & Sarjana & 227 \\
\hline 6 & Magister & 42 \\
\hline 7 & Doktor & 14 \\
\hline & Total & 1.942 \\
\hline
\end{tabular}

Sumber : data primer diolah
Pada Tabel 2 menunjukkan bahwa tingkat pendidikan yang menamatkan perguruan tinggi mulai dari Diploma sampai Doktor berjumlah 334 atau 13\%, sedangkan pendidikan dari SD sampai SMA atau SMK sebanyak 1.608 orang atau $64 \%$ dan sisanya $23 \%$ tidak sekolah atau buta huruf sebanyak 557 orang jumlah yang sangat signifikan.

Penelitian ini mengambil sampel $10 \%$ dari jumlah pengusaha atau wirausaha pada Tabel 1 nomor lima (5) sebanyak 189 orang. Jadi sampel diambil sebanyak 20 orang dengan ketentuan diambil secara acak dan dibagi tiga kolompok yaitu 1) Usaha dagang sebanyak 6 orang, 2) Wirausaha 7 orang, dan 3) Belum bekerja sebanyak 7 orang. Dari Tabel 2 menunjukkan bahwa tingkat pendidikan masyarakat desa Baumata Barat kebanyakan tamatan SLTA. Pengukuran indikator yang di gunakan dalam mengukur prestasi kerja meliputi, 1) Kecepatan dalam pekerjaan, 2) Keberhasilan dalam menyelesaikan pekerjaan, 3) Kualitas kerja yang dihasilkan, 4) Bekerja dengan rekan kerja, 5) Kecekatan mental (Rofi, 2012). Upaya untuk memaksimalkan kualitas SDM dapat di mulai dari pemilihan tenaga kerja yang berpengalaman dengan tingkat pendidikan yang sesuai dalam bekerja, penjabaran fungsi pengembangan tenaga kerja, dan sumber daya manusia yang memiliki organisasi harus memperhatikan tingkat pendidikan dan pengalaman kerja dengan sebaik-baiknya, dengan adanya SDM yang baik maka akan terciptakan kinerja yang tinggi (Nitisimito dalam Ardiyansyah, 2016).

Uji validitas dengan menggunakan software SPSS for Windows seri 16.0, diperoleh hasil uji-t bahwa seluruh item pertanyaan adalah valid karena masingmasing nilai item corrected item total correlation memiliki nilai lebih besar dari standar minimum $(0,9)$ untuk jelasnya disajikan pada Tabel 3. Dari Tabel 3 di bawah ini tampak bahwa seluruh item pertanyaan adalah valid karena masing-masing item nilai corrected Item-total correlation memiliki nilai lebih besar dari standar minimum $(0,3)$. 
Tabel 3. Rangkuman Uji Validitas

\begin{tabular}{|c|c|c|c|c|c|}
\hline $\begin{array}{c}\text { No } \\
\text { soa } \\
\mathrm{I}\end{array}$ & $\begin{array}{c}\mathrm{r} \\
\text { hitung } \\
(\mathrm{X} 1)\end{array}$ & $\begin{array}{c}\mathrm{r} \text { hitung } \\
(\mathrm{X} 1)\end{array}$ & $\begin{array}{c}\mathrm{r} \text { hitung } \\
(\mathrm{Y})\end{array}$ & Syarat & $\begin{array}{c}\text { Keterang - } \\
\text { an }\end{array}$ \\
\hline 1 & 0.603 & 0.672 & 0.366 & $>0.300$ & $\begin{array}{c}\text { Item Soal } \\
\text { Valid }\end{array}$ \\
\hline 2 & 0.542 & 0.375 & 0.355 & $>0.300$ & $\begin{array}{c}\text { Item Soal } \\
\text { Valid }\end{array}$ \\
\hline 3 & 0.564 & 0.592 & 0.592 & $>0.300$ & $\begin{array}{c}\text { Item Soal } \\
\text { Valid }\end{array}$ \\
\hline 4 & 0.583 & 0.724 & 0.363 & $>0.300$ & $\begin{array}{c}\text { Item Soal } \\
\text { Valid }\end{array}$ \\
\hline 5 & 0.736 & 0.348 & 0.520 & $>0.300$ & $\begin{array}{c}\text { Item Soal } \\
\text { Valid }\end{array}$ \\
\hline 6 & 0.672 & 0.487 & 0.608 & $>0.300$ & $\begin{array}{c}\text { Item Soal } \\
\text { Valid }\end{array}$ \\
\hline 7 & 0.618 & 0.805 & 0.566 & $>0.300$ & $\begin{array}{c}\text { Item Soal } \\
\text { Valid }\end{array}$ \\
\hline 8 & 0.520 & 0.405 & 0.615 & $>0.300$ & $\begin{array}{c}\text { Item Soal } \\
\text { Valid }\end{array}$ \\
\hline
\end{tabular}

Sumber : data primer diolah

Hasil pengujian hipotesis memberikan gambaran bahwa secara statistik (multiple correlation coefficient) dapat dikatakan bahwa variabel-variabel bebas mampu memprediksi variabel terikat. Kisaran nilai $R$-square adalah 0 hingga 1 . Semakin nilai $R$-square mendekati angka 1 maka dapat dikatakan variabel variabel bebas mampu memprediksikan variabel terikat. Kolom $R$-square/ Adjusted $R$ square dengan menggunakan tingkat keyakinan $95 \%$ alpha $=5 \%$ menunjukkan angka 0.188/0.078. Hal ini menunjukkan pengaruh yang relatif kecil, yang mana dapat dikatakan bahwa variabel peluang usaha tidak dapat diprediksi oleh variabel sikap, minat dan motivasi individu yang mana hal tersebut bisa disebabkan oleh sampel yang dituju masih memerlukan pembinaan tentang ilmu kewirausahaan.

Hasil analisis model pengujian dengan uji-F diperoleh nilai F-hitung sebesar 0,313. Dengan menggunakan tingkat signifikasi menggunakan alpha $=5 \%$ (signifikansi $5 \%$ atau 0,05 , sedangkan nilai $F$-tabel sebesar 3,683 sedangkan uji statistik, hipotesisnya adalah :

Ho : $B 1=B 2=0$, Variabel sikap, minat dan motivasi tidak berpengaruh signifikan terhadap peluang usaha.

Ha: $\beta 1 \neq \beta 2 \neq 0$, Variabel sikap, minat dan motivasi berpengaruh signifikan terhadap peluang usaha.

Dengan kriteria jika F-hitung $\leq$ F-tabel maka Ho diterima, sebaliknya F-hitung $\geq$ F-tabel maka Ho ditolak atau Ha diterima.

Hasil penelitian diperoleh bahwa Fhitung $\leq \mathrm{F}$-tabel, dengan demikian dapat dikatakan bahwa Ho diterima atau Ha ditolak. Jadi dapat disimpulkan bahwa variabel sikap, minat dan motivasi tidak berpengaruh signifikan terhadap peluang usaha, artinya masih diperlukan pembinaan selanjutnya bagi masyarakat responden. Kedepannya penelitian ini terus di kembangkan dan menerapkan motivasi, sikap dan minat berwirausaha dengan menambah model permainan wirausaha yang dikembangkan dalam bentuk permainan, sehingga diharapkan pengembangan model pelatihan dalam bentuk permainan tersebut mampu menghasilkan uji hipotesis yang lebih baik.

Pelatihannya dapat dikatakan berhasil apabila pedagang sebagai sasaran akan diberikan bimbingan dengan sistem pemberian suntikan modal bagi yang sudah membuka usaha sebagai uji coba pengembangan usaha mandiri. Untuk itu penelitian ini akan terus di kembangkan sampai keberhasilan membuka usaha dan ada perubahan keberhasilan yang nyata.

\section{PENUTUP}

Dari hasil penelitian dapat disimpulkan bahwa nilai koefiesien korelasi berganda menunjukkan angka R-square $(0,188)$ menunjukkan adanya pengaruh yang termasuk katagori rendah atau lemah, hal tersebut bisa disebabkan oleh sampel yang dituju masih memerlukan pembinaan tentang ilmu kewirausahaan. Demikian pula dengan hasil pengujian hipotesis dengan uji $F$ yang menunjukkan bahwa F-hitung $\leq$ F-tabel $(0,313$ $\leq 3,683$ ) yang artinya variabel sikap, motivasi dan minat tidak berpengaruh signifikan terhadap peluang usaha. Hal tersebut disebabkan karena sebagian besar responden sampel belum memahami tentang kewirausahaan. Untuk itu penelitian ini akan terus dikembangkan sampai ada sikap, motivasi dan minat berwirausaha.

Disarankan untuk penelitian lebih lanjut dapat menguji kembali variabel motivasi, sikap dan minat para pengusaha. Dari hasil penelitian ini sebagian besar masyarakat belum mempunyai minat berwirausaha. Memberikan wawasan berwirausaha merupakan suatu pilihan masa yang akan datang dengan memberikan bimbingan wirausaha. Pemupukan jiwa kewirausahaan dengan pelatihan -pelatihan kewirausahaan, melatih kepercayaan diri di harapkan akan mengubah pendapat bahwa wirausaha akan dapat menjanjikan kehidupan yang lebih baik mendorong minat berwirausaha 


\section{DAFTAR PUSTAKA}

Ardiyansyah, Sjadhruddin H., \& Idris M. H. (2014), Pengaruh Tingkat Pendidikan dan Pengalaman Kerja Terhadap Prestasi Kerja Karyawan Pada PT. Adira Quantum Multifinance Cabang Makasar, E- Library STIE YPBUP Bonggala 2014

Agustina \& Sularto (2011), Intensi Kewirausahaan Mahasiswa (Studi Perbandingan antara Fakultas Ekonomi dan Fakultas IImu Komputer). Proceeding Pusat Universitas Guna Darma- Depok 18-Oktober 2011.

Budiati Y, Tri E., \& Nuria U, (2012), Minat Mahasiswa menjadi Wirausaha (Studi mahasiswa fakultas ekonomi Universitas Semarang. Jurnal DINAMIKA SOSBUD Volume 14 nomor 1, juni $2012: 89-101$.

Baum J.R., Frese M., dan Robert A. (2007), The Psychology of Entrepreneurship. London : Routledge

Hisrich, R. (2001), Entrepreneurship Kewirausahaan. Salemba Empat . Jakarta.

Kuncoro,M. (2003), Metode Riset untuk bisnis \& Ekonomi. Erlangga. Jakarta.

Mulyaningsih (2012), Faktor - faktor yang mempengaruhi minat wirausaha pengelola pangan organik. Malang : Jurnal Wacana

Santoso (2002), Buku Latihan SPSS: Statistik Parametrik. Cetakan ketiga. Jakarta : PT. Elex Media Komputindo

Sugiyono (2007), Metode Penelitian Pendidikan ,Pendekatan Kuantitatif, Kualitatif, dan R\&D. Bandung : Alfabeta

Sumardi (2007), Menakar Seberapa Besar Jiwa Wirausaha Mahasiswa Teknik Mesin FPTK UPI. Jakarta.

Soemanto (2002), Mengaktualisasikan Sikap dan Perilaku Wirausaha. Jurnal Online, Sabtu, 2-10-2013

Sarosa \& Pietra (2005), Becoming Young Entrepreneur: Dream Big Start Small, Act Now! Panduan Praktis \& Motivasional Bagi Kaum Muda dan Mahasiswa. Jakarta : PT Elax Media Komputindo

Suharyadi (2000), Menakar Jiwa Wirausaha Mahasiswa Teknik Mesin Angkatan 2005, Jurnal Penelitian, Universitas
Indonesia .

Widoyoko S. E. P. (2012), Teknik Penyusunan Instrumen Penelitian, Jogyakarta: Pustaka Pelajar 